\title{
Determination of Free Tryptophan in Beer Samples by Capillary Isotachophoretic Method
}

\author{
Aneta Jastrzębska $^{1}$ (D) Sylwia Kowalska ${ }^{1} \cdot$ Edward Szłyk $^{1}$
}

Received: 29 August 2019 / Accepted: 9 January 2020 / Published online: 17 January 2020

(C) The Author(s) 2020

\begin{abstract}
Tryptophan is essential amino acid and precursor for many neurotramsmiters that must be obtained from dietary proteins. However, its free form is easily absorbed and could increase the availability of this amino acid to the brain. Because of free tryptophan interaction with human health simple, eco-friendliness and low-cost method of determination are still needed. In this study, new and simple procedure for free tryptophan determination using capillary isotachophoresis is discussed. The method validation pointed good linearity, satisfactory selectivity, accuracy (recoveries varied from 98.4 to 100.1\%), intra- and inter-day precision (coefficent of variation was $<5 \%$ for each standard solution and $<6 \%$ for real samples) and no matrix effect. The proposed procedure was successfully applied to analyse free tryptophan in beer samples and found contents varied from not detected to $40.74 \pm 0.27 \mathrm{mg} \mathrm{L}^{-1}$. The obtained results were compared with chromatographic determination after derivatization with 2-chloro-1,3-dinitro5-(trifluoromethyl)benzene and pointed better selectivity and accuracy of isotachophoretic procedure with similar precision. Due to the simplicity and flexibility, the proposed procedure is suitable for tryptophan analysis in complex matrices.
\end{abstract}

Keywords Beer samples · Capillary isotachophoresis · 2-chloro-1,3-dinitro-5-(trifluoromethyl)benzene · Tryptophan

\section{Introduction}

Tryptophan (Trp) is large neutral amino acid (LNAA) and precursor for brain neurotransmitters (serotonin, melatonin, tryptamine, quinolinic acid and kynurenic acid). According to Friedman (2018), dietary Trp and its metabolites may contribute to the therapy of many diseases, cognitive function, depression, sleep and social function. However, this hypothesis is still under discussion (Soh and Walter 2011). The main source of this amino acid is protein-based food including meats, dairy products, fruits and seeds (Jenkins et al. 2016). On the other hand, the protein-rich diet results in an increase of tyrosine content in relation to other LNAA and reduces the available tryptophan for transport across the blood-brain barrier, whereas carbohydrate-rich food with high-glycaemic index is found to increase the availability of tryptophan (Markus 2008; Jenkins et al. 2016).

Beer is an example of food rich in carbohydrates, amino acids and other compounds, such as antioxidants, minerals, B-

Aneta Jastrzębska

aj@ chem.uni.torun.pl

1 Faculty of Chemistry, Nicolaus Copernicus University in Torun, Gagarin 7 Str, 87-100 Torun, Poland vitamins and soluble fibre (Kabelová et al. 2008). It is the world's oldest and most widely consumed alcoholic beverage in the world, and its moderate consumption has been associated with several health benefits (de Gaetano et al. 2016). These beverages produced from various raw materials and are complex mixture of more than 800 chemical compounds, widely varying depending on the production procedures and environment. One class of compounds, amino acids, is metabolized by yeast during fermentation, and their presence in beer contributes to the fullness and nutritional value of beer (Zhu et al. 2010). Usually, the most abundant amino acid in beer is proline (Guo et al. 2019), whereas Trp was also detected (Palomino-Vasco et al. 2019; Redruello et al. 2017). Compared to Pro, tryptophan is usually determined in beer at low levels (Poveda 2019; Shi et al. 2009). This amino acid is the precursor for biologically active compounds (such as melatonin, serotonin and tryptophol) which are prodused by yeast metabolism, and its content is respectively associated to bitter sensation in taste perception of beer (Fontana and Buiatti 2009). However, detailed information about the content of this amino acid in beverages in free form is still limited. Moreover, beers contain only low levels of amino acids, since during fermentation, amino acids are assimilated for yeast growth. For this reason, elaboration of a suitable and selective procedure for amino acids determination is still valid. 
The determination of amino acids in food, including beer samples, has been carried out employing different techniques, while the most popular are as follows: capillary electrophoresis (Cortacero-Ramírez et al. 2004; Guo et al. 2019; Luo et al. 2017; Turkia et al. 2015) and liquid chromatography with different detection systems (Liyanaarachchi et al. 2018; Moreno-Rojas et al. 2018; Palomino-Vasco et al. 2019; Poveda 2019; Redruello et al. 2017). Recently, micellar electrokinetic chromatography and micellar liquid chromatography were described as alternative method to classical HPLC (Ke et al. 2017; Ke et al. 2019; Tezcan et al. 2013; Yan et al. 2014) and applied for beverage samples (Gil-Agustí et al. 2007; Huang et al. 2019; Xie et al. 2018).

It should be noted that, despite the technical progress, chromatographic measurements are still expensive and susceptible to interference and require sophisticated method of sample preparation. Moreover, some of HPLC procedures for amino acids suffer from long run time and poor resolution between some amino acids. These problems minimize the use of capillary isotachophoresis (ITP). ITP is a promising technique for the analysis of food composition that delivers satisfactory results rapidly and efficiently with uncomplicated procedure for analysis and the minimal sample preparation. This method is still developing and very often combined with other methods what follows with the ability to concentrate trace analytes. The progress on analytical applications of ITP is systematically published since 1997 (Gebauer and Boček 1997; Malá and Gebauer 2019). The simple determination of amino acids in different samples by ITP was proposed by some Authors (Jastrzębska et al. 2013, 2015; Kubačák et al. 2006; Kvasnička and Krátká 2006; Prest et al. 2004; ZgolaGrześkowiak and Grześkowiak 2012); however, Trp was not satisfactory separated in the described electrolyte systems. ITP allows for simple and direct analysis of amino acids as well as after their derivatization (Kováŕová et al. 2018). However, to the best of our knowledge, there are no references on the satisfactory separation and determination of Trp in beer samples by this method.

For this purpose, the main goal of this paper was determination of free Trp in beers (ale, lager, pilsner, porter, hop, wheat and beer drink) using simple ITP procedure. The proposed procedure was optimized and validated for linearity, limit of detection and quantification, selectivity and matrix effects, intra- and inter-day precision and recovery. The obtained results of Trp determination in beer samples by ITP were compared with chromatographic analyses of Trp derivative with 2-chloro-1,3-dinitro-5-(trifluoromethyl)-benzene (CNBF) (Guo et al. 2015; Li et al. 2012; Piasta et al. 2014; Shi et al. 2009). This reagent seems to be proper choice for amino acids determination due to its fast reaction with nucleophiles at moderate temperatures while obtained derivatives are stable and reveals high ultraviolet absorption. Both procedures (ITP and HPLC) were compared and discussed with regard of simplicity, flexibility and possible application for beer sample analyses.

\section{Materials and Methods}

\section{Reagents and Apparatus}

Analytical grade: L-tryptophan (Trp), L-tyrosine (Tyr), Lthreonine (Thr), L-methionine (Met), L-valine (Val), L-isoleucine (Ile), L-histidine (His), L-phenylalanine (Phe), Larginine (Arg), L-leucine (Leu), L-proline (Pro), L-lysine (Lys), $\beta$-alanine (Ala), L-glutamic acid (Glu), glycine (Gly), tryptamine (Trp), 2-chloro-1,3-dinitro5-(trifluoromethyl)benzene (CNBF), methanol (HPLC grade), acetonitrile (HPLC grade), triethylamine, 1,3bis[tris(hydroxymethyl)methylamino]propane (BTP), 6aminocaproic acid (EACA), 2-amino-2-methyl-1,3propanediol (AMPD), tris(hydroxymethyl)aminomethane (TRIS), ethanamine and hydroxyethylcellulose (HEC, average $M_{v} \sim 90.000$ ) were purchased from Sigma-Aldrich (Poland). Hydrochloric acid, boric acid, sodium chloride, sodium tetraborate and potassium dihydrogen phosphate were purchased from Alchem (Toruń, Poland). Deionized water was used for all solutions.

Isotachophoretic separations were performed using a Villa Labeco EA 102 isotachophoretic analyser (Villa Labeco, Spišská Nová Ves, Slovakia) equipped with two columns employing capillaries made of fluorinated ethylenepropylene copolymer (FEP): preseparation column (inner diameter $0.8 \mathrm{~mm}$ and long $90 \mathrm{~mm}$ ) and analytical column (inner diameter $0.3 \mathrm{~mm}$ and long $180 \mathrm{~mm}$ ). Both capillaries were equipped with contact conductivity detectors. The isotachopherograms were evaluated using the software supplied with analyser. The HPLC system (SHIMADZU, Japan), equipped with an autosampler SIL-20AC HT and a photodiode multi-wavelength detector (SPD-M20A Prominence Diode Array Detector) was applied. The chromatographic data were recorded and processed by the LC solution program version 1.23 SP. Prior to the analysis, beer samples were degassed in an ultrasonic cleaner (Chemland, Poland). Deionized water was obtained from demineralised water supplier (Hydrolab, Poland).

\section{ITP Procedure}

The isotachophoretic analysis of tryptophan was performed with leading electrolyte (LE): $10 \mathrm{mM} \mathrm{HCl}+1 \%$ hydroxyethylcellulose, HEC and $20 \mathrm{mM}$ 1,3bis[tris(hydroxymethyl)methylamino]propane, BTP $(\mathrm{pH}=9)$ and terminating electrolyte (TE): $10 \mathrm{mM} 6$-aminocaproic acid, EACA + 20 mM 2-amino-2-methyl-1,3-propanediol, AMPD 
$(\mathrm{pH}=9)$. A driving current of the preseparation column was $200 \mu \mathrm{A}$, which during detection decreased to $120 \mu \mathrm{A}$.

The Trp in standard solution and food samples was identified by the relative step height parameter ( $\mathrm{RSH})$, which was calculated from the relation: $\mathrm{RSH}=(\mathrm{HX}-\mathrm{HL}) /(\mathrm{HT}-\mathrm{HL})$, where HX - zone height of tested ion, HL and HT-step height of leading and terminating ion, respectively. Standard stock solution of tryptophan $\left(100 \mathrm{mg} \mathrm{L}^{-1}\right)$ was prepared by dissolution in distilled water with the addition of $5 \mathrm{mM}$ nitric acid. Calibration curves were constructed using eight calibration solutions of the Trp in the range $20-100 \mathrm{mg} \mathrm{L}^{-1}$. The results were calculated as an average of three replicates for each solution.

\section{Validation Study of ITP Procedure}

ITP procedure validation test was performed for selectivity, linearity range, accuracy, precision, limits of detection (LOD) and quantification (LOQ). Each solution was measured in triplicate, and recoveries are average values from all measurements. Data were expressed as average \pm standard deviation (SD). The precision study of $\mathrm{RSH}$ values including repeatability and reproducibility was carried out for standard solutions of $\operatorname{Trp}\left(50 \mathrm{mg} \mathrm{L}^{-1}\right.$ and $\left.90 \mathrm{mg} \mathrm{L}^{-1}\right)$. Subsequently, the stability of the RSH measurements was tested using Trp solutions and blank sample. Within-day analyses were determined by injection of the tested samples three times per day. The intralaboratory reproducibility was determined by triple analysis of the tested solutions during 5 consecutive days.

The selectivity of ITP procedure was tested by adding to the solution selected interferences (such as other LNAA and essential amino acids and tryptamine) in the presence of Trp. The accuracy was determined using recovery test of the Trp solution (20 $\mathrm{mg} \mathrm{L}^{-1}, 50 \mathrm{mg} \mathrm{L}^{-1}$ and $75 \mathrm{mg} \mathrm{L}^{-1}$ of Trp in the presence of other compounds) and recovery tests by adding a known amount of $\operatorname{Trp}\left(20 \mathrm{mg} \mathrm{L}^{-1}, 50 \mathrm{mg} \mathrm{L}^{-1}\right.$ and $75 \mathrm{mg} \mathrm{L}^{-1}$ ) to the beer samples and analysis of unspiked and spiked samples. The recovery values were calculated by comparing the concentration of Trp in both samples. The slope comparison method was used to evaluate the matrix effect (Jia et al. 2011). The beverages samples $(1 \mathrm{~mL})$ were spiked with the appropriate amounts of $\operatorname{Trp}(2,4,5,6$ and $8 \mathrm{~mL}$ of working solution of Trp) and used for calibration procedure. The calibration curves were developed with three independent replicates at each concentration, and obtained average slope of the calibration curves from the standard addition experiments was compared with the slopes obtained from the standards solutions at the same concentration levels (Student's $t$ test).

One-way analysis of variation (ANOVA), followed by the Duncan test, was performed to analyse the significant differences between mean data obtained by ITP and HPLC procedures $(p<0.05)$ using the Statistica (Windows software package) (version 8.0, 2007).

\section{RP-HPLC Procedure}

HPLC measurements of Trp-CNBF derivative were performed using following solvent system: acetonitrile (A) and mixture of acetate buffer $\left(0.05 \mathrm{~mol} \cdot \mathrm{L}^{-1}\right)+$ acetonitrile + triethylamine $(82.8: 17: 0.2 \mathrm{v} / \mathrm{v} / \mathrm{v})(\mathrm{B})$. The gradient elution was employed: 0 min: $20 \% \mathrm{~A}, 80 \% \mathrm{~B} ; 15 \mathrm{~min}: 38 \% \mathrm{~A}$, $62 \%$ B; 35 min: $48 \%$ A, $52 \%$ B; 43 min: $75 \%$ A, 25\% B; and 55-65 min: $20 \% \mathrm{~A}, 80 \% \mathrm{~B}$ (Li et al. 2012). The flow rate was $0.32 \mathrm{~mL} \mathrm{~min}^{-1}$, the detection wavelength was $260 \mathrm{~nm}$ and the temperature was set at $30^{\circ} \mathrm{C}$. Analyses were carried out on a OP-C18 (5 $\mu \mathrm{m}$ particle size, $250 \times 4.6 \mathrm{~mm})$ column.

Standard stock solution of tryptophan was prepared in borate buffer $(\mathrm{pH}=9)$. The solution of tryptophan $(1 \mathrm{~mL})$ was mixed with 4-chloro-3,5-dinitrobenzotrifluoride in acetonitrile $\left(1.5 \mathrm{~mL} ; 0.2 \mathrm{~mol} \mathrm{~L}^{-1}\right)$ in the presence of borate buffer and incubated at $60{ }^{\circ} \mathrm{C}$ for $30 \mathrm{~min}$. Next, $10 \mu \mathrm{L}$ of $\mathrm{HCl}$ $\left(2 \mathrm{~mol} \mathrm{~L}^{-1}\right)$ was added to stop the reaction and finally obtained solutions were made up to the $25 \mathrm{~mL}$ by phosphate buffer $(\mathrm{pH}=7)$. Calibration curves were constructed using eight calibration solutions of the Trp in the range $1.63-81.69 \mathrm{mg} \cdot \mathrm{L}^{-1}$ by appropriate dilution of the obtained solutions in phosphate buffer. Test for matrix effect was conducted by standard addition method ( $\mathrm{Li}$ et al. 2012). The obtained regression equations were as follows: $y=258,715 \cdot \mathrm{C}-35,989\left(R^{2}=0.9999\right.$; detection limit, $\mathrm{LOD}=0.31 \mathrm{mg} \mathrm{L}^{-1}$ and quantification limit, $\left.\mathrm{LOQ}=0.94 \mathrm{mg} \mathrm{L}^{-1}\right)$ for standard solution of Trp and $y=$ $258,239 \cdot \mathrm{C}-17,500\left(R^{2}=0.9993 ; \mathrm{LOD}=4.35 \mathrm{mg} \mathrm{L}^{-1}\right.$; $\mathrm{LOQ}=13.18 \mathrm{mg} \mathrm{L}^{-1}$ ) for blank matrix with Trp.

\section{Sample Collection and Preparation}

Sixteen samples of commercial bottled beer with different contents of alcohol by volume (ABV) were purchased from the three brands origin Poland marked as B1, B2 (main popular brands available on the Polish market) and B3 (microbrewery). Tested beers included the following: strong lager (sample 1, B1, ABV 6.8\%), unpasteurized lager (sample 2, B1, ABV 5.4\% and sample 3, B3, ABV 5.2\%), pilsner (sample 4, B1, ABV 5.7\% and sample 5, B3, ABV 5.6\%), lager (sample 6, B1, ABV 5.0\% and sample 7, B2, ABV 5.0\%), wheat (sample 8, B2, ABV 5.0\%), hop (sample 9, B1, ABV $6.0 \%$ and sample 10, B3, ABV 6.1\%), porter (sample 11, B1, ABV 9.6\% and sample 12, B2, ABV 9.5\%), ale (sample 13, B1, ABV 5.1\% and sample 14, B3, ABV 5.0\%) and two samples of beer drink: apple (sample 15, B1, ABV 4.5\%) and blackberry (sample 16, B1, ABV 4.5\%). The samples were purchased on local markets in 2018 (samples: 1, 2, 4, $6,8,9,11,13,14$ and 15) and in 2019 (samples: 3, 5, 7, 10, 12 and 14) years and stored in the dark at low temperatures $\left(5^{\circ} \mathrm{C}\right)$. All samples were degassed by ultrasonication and filtered prior to analysis. 
For ITP procedure, $9 \mathrm{~mL}$ of sample was filled up to the $10 \mathrm{~mL}$ by the deionized water. For HPLC analysis, the solution of beverage samples $(0.4 \mathrm{~mL})$ was mixed with CNBF solution $\left(0.60 \mathrm{~mL}, 0.2 \mathrm{~mol} \mathrm{~L}^{-1}\right)$ in the presence of borate buffer $(\mathrm{pH}=9)$ and incubated at $60^{\circ} \mathrm{C}$ by $30 \mathrm{~min}$. The solution of $\mathrm{HCl}$ was added to stop the reaction and finally obtained solutions were made up to the $10 \mathrm{~mL}$ by phosphate buffer $(\mathrm{pH}=7)$ (Li et al. 2012). The derivatized samples were filtered $(0.45 \mu \mathrm{m}$ pore size filter) prior to HPLC analysis.

For each tested beverages, three independent samples were used for all procedures and each sample was analysed in triplicate.

\section{Results and Discussion}

\section{Elaboration of the ITP Method Conditions}

Based on the amphoteric character of amino acids and low mobility in electric field, their separation by ITP in $\mathrm{pH} 3-10$ is difficult (Kovářová et al. 2018). However, many authors (Everaerts et al. 1976; Kubačák et al. 2006; Kvasnička and Krátká 2006; Prest et al. 2004; Zgola-Grześkowiak and Grześkowiak 2012) described the application of ITP for amino acid determination and this method appears to be complementary to existing procedures. According to Everaerts et al. (1976), if the $\mathrm{pH}$ of the leading electrolyte is above 8, most amino acids will have an effective mobility suitable for isotachophoretic separation. For example, Hirokawa et al. (1983) reported separation of amino acids at $\mathrm{pH}$ 8.6-9.6 finding optimal separation at $\mathrm{pH} 8.64$, whereas $\mathrm{pH}=9.7$ was also proposed (Prest et al. 2004). On the other hand, ITP analysis using alkaline electrolyte brings a problem with migration of carbonate what can be associated with mixed zones creation (Everaerts et al. 1976; Kovářová et al. 2018). Hirokawa et al. (1991) studied the dilution and elongation of ITP zones by carbonate ions from the terminating electrolyte and concluded that in the analysis of amino acid anions, under $\mathrm{pH}$ between 8 and 10 , the carbonate zone migrates before the sample zones.

The isotachophoretic separation of Trp is imposed mainly by composition of leading and terminating electrolytes. In this paper, we proposed determination of $\operatorname{Trp}\left(\mathrm{pI}=5.89 ; \mathrm{p} K_{1}=2.38 ; \mathrm{p} K_{2}=\right.$ 9.39) as anion in alkaline electrolyte. For this purpose, leading and termination ion concentrations, buffering ions and analytical conditions (current and time) were proposed and discussed. Solutions of $10 \mathrm{mM}$ hydrochloric acid and $10 \mathrm{mM} \mathrm{6-}$ aminocaproic acid were used as the leading and termination ions, respectively. The presence of hydroxyethylcellulose (1\% HEC) in the leading electrolyte suppresses the undesired electroosmotic flow, resulting in zones boundaries sharpening. The $\mathrm{pH}=9$ was chosen for leading and terminating electrolyte (Hirokawa et al. 1991; Prest et al. 2004). The composition of the LE and TE was optimized with regard to type of counter ion. Four compounds were tested to obtain selected $\mathrm{pH}$ in LE and TE: tris(hydroxymethyl)aminomethane (TRIS; $\mathrm{p} K_{\mathrm{a}}=8.07$; useful $\mathrm{pH}=7.2-9.0$ ), 2-amino-2-methyl-1,3-propanediol (AMPD; p $K_{\mathrm{a}}=8.78$; useful pH range 7.8-9.7), 1,3bis[tris(hydroxymethyl)methylamino]propane (BTP; $\mathrm{p} K_{\mathrm{a}}=6.8$ and 9.00; useful $\mathrm{pH}$ range 6.3-9.5) and ethanamine with $\mathrm{p} K_{2}=$ 10.87 (Kvasnička and Krátká 2006). Trp zone presence, its length, RSH parameter and time of analysis were monitored. It was found that all buffers (BTP, TRIS and AMPD) allowed for qualitative analysis of Trp, whereas for ethanamine in LE or TE, the separation of Trp was not observed. The example of isotachopherograms of Trp separation $\left(100 \mathrm{mg} \cdot \mathrm{L}^{-1}\right)$ recorded by tested five electrolyte systems (A-F) is presented on Fig. 1.

Among the tested electrolyte system setups, the best results in regard of separation conditions (RSH parameter, sharpness of the zone boundaries, zone length, finally negligence of carbonate influence on the separation process and time of analysis) were achieved for the A and B (Fig. 1), respectively. For the other buffer compositions, some inconveniences were observed: long time of analysis (D and E electrolyte systems), no sharp boundaries of the Trp zone (C electrolyte system) or location of the Trp zone near to TE (F electrolyte system) (Fig. 1). The chosen compositions of electrolytes (A and B) were examined for the precision of Trp solution determination $\left(100 \mathrm{mg} \mathrm{L}^{-1}\right)$ and obtained values of variation coefficients for RSH parameter $\left(\mathrm{CV}_{\mathrm{RSH}}\right)$ and zone length $\left(\mathrm{CV}_{\mathrm{L}}\right)$ were as follows: $0.52 \%$ and $1.69 \%$ (A electrolyte system) and $2.14 \%$ and $8.13 \%$ (B electrolyte system), respectively. Comparing the obtained precision for both selected setups, the best results of the Trp separation were achieved for the A electrolyte system (LE: $10 \mathrm{mM} \mathrm{HCl}+1 \% \mathrm{HEC}+\mathrm{BTP}$ to $\mathrm{pH}=9.0$ and TE $=$ $10 \mathrm{mM}$ EACA + AMPD to $\mathrm{pH}=9$ ), which was chosen for further analysis.

In the last step, optimum driving current during detection $(200 \mu \mathrm{A}, 120 \mu \mathrm{A}, 100 \mu \mathrm{A}, 80 \mu \mathrm{A}$ and $50 \mu \mathrm{A})$ was tested. Application of current below $100 \mu \mathrm{A}$ resulted in an extended time of analysis, whereas driving current about $200 \mu \mathrm{A}$ allowed for quick analysis but generated high voltage in the separation capillary and negative effects of Joule heating. Finally, $120 \mu \mathrm{A}$ as the driving current was applied.

\section{Method Validation Results}

The following parameters were evaluated in the validation procedure of chosen system of electrolytes: selectivity of the ITP determination, precision (repeatability and reproducibility) and accuracy, linearity, limit of detection (LOD) and limit of quantification (LOQ) and matrix effect. Intra- and inter-day precision of RSH values for Trp solutions (standard and blank matrix) and the regression equations for Trp in standards and blank matrix solutions were calculated and are listed in Table 1. 
Fig. 1 Isotachopherograms of Trp standard solution

(100 $\mathrm{m} \mathrm{L}^{-1}$ ) determination by electrolyte systems: (A) LE: $10 \mathrm{mM} \mathrm{HCl}+1 \% \mathrm{HEC}+\mathrm{BTP}$ to $\mathrm{pH}=9$; TE: $10 \mathrm{mM}$ EACA + AMPD to $\mathrm{pH}=9$; (B) $10 \mathrm{mM}$ $\mathrm{HCl}+1 \% \mathrm{HEC}+\mathrm{TRIS}$ to $\mathrm{pH}=$ 9; TE: 10 mM EACA + AMPD to $\mathrm{pH}=9$; (C) $10 \mathrm{mM} \mathrm{HCl}+1 \%$ $\mathrm{HEC}+\mathrm{AMPD}$ to $\mathrm{pH}=9$; TE: $10 \mathrm{mM}$ EACA + TRIS to $\mathrm{pH}=9$; (D) $\mathrm{LE}: 10 \mathrm{mM} \mathrm{HCl}+1 \%$ $\mathrm{HEC}+\mathrm{AMPD}$ to $\mathrm{pH}=9$; TE: $10 \mathrm{mM}$ EACA + AMPD to $\mathrm{pH}=$ 9; (E) LE: $10 \mathrm{mM} \mathrm{HCl}+1 \%$ $\mathrm{HEC}+\mathrm{TRIS}$ to $\mathrm{pH}=9$; TE: $10 \mathrm{mM}$ EACA + TRIS to $\mathrm{pH}=9$; (F) LE: $10 \mathrm{mM} \mathrm{HCl}+1 \% \mathrm{HEC}+$ BTP to $\mathrm{pH}=9$; TE: $10 \mathrm{mM}$ $\mathrm{EACA}+\mathrm{BTP}$ to $\mathrm{pH}=9$
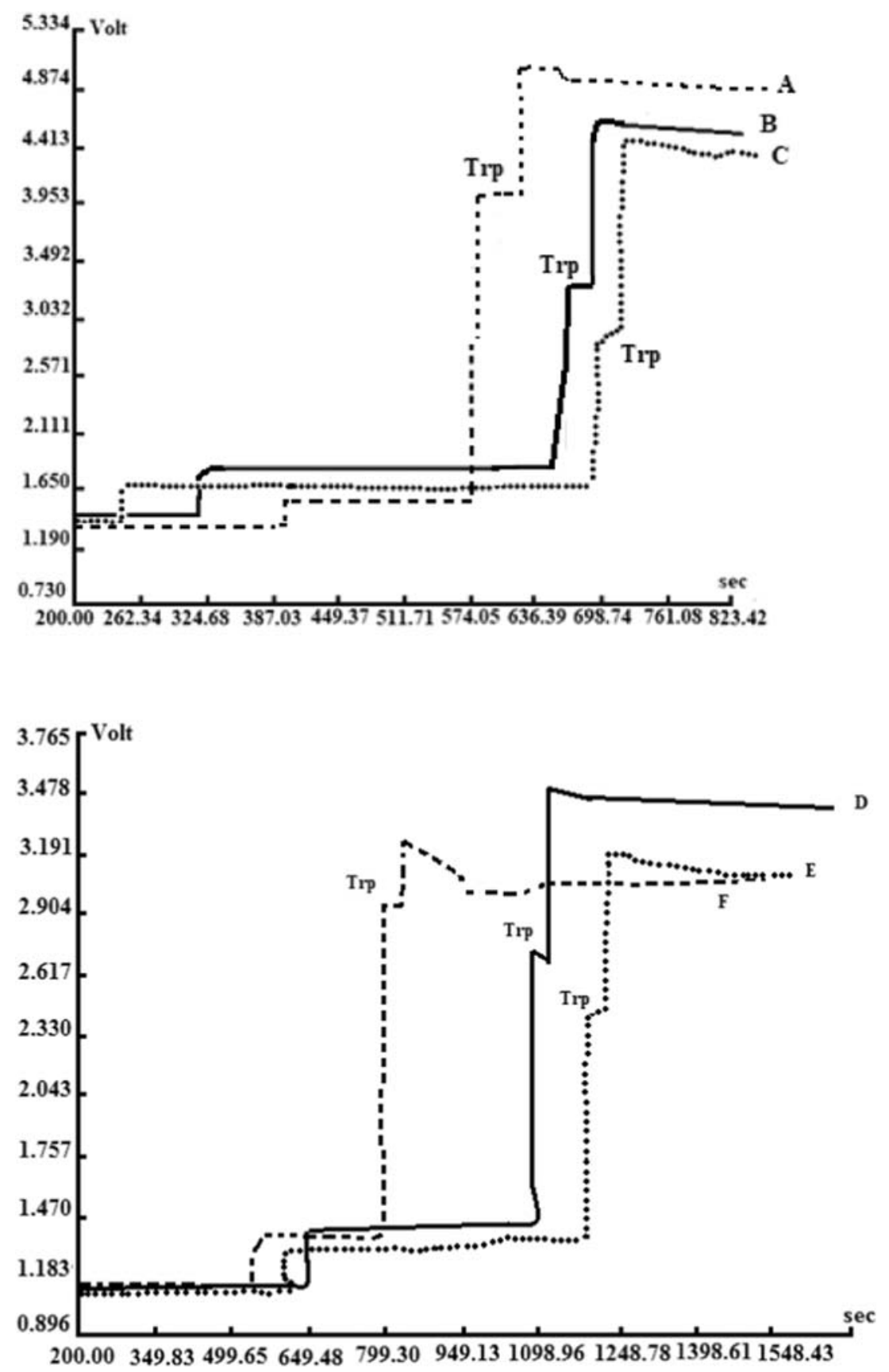

The separation of Trp in the standard and blank matrix solutions resulted in within-day and between-day $\mathrm{CV}_{\mathrm{RSH}}$ in the ranges $0.52-1.17 \%$ and $2.64-4.83 \%$, respectively, which indicated reasonable repeatability and intralaboratory reproducibility and confirmed the stability of the proposed ITP procedure. To the best of our knowledge, there is no data on the ITP procedure for tryptophan determination. For this reason, it is difficult to compare the obtained results with the literature. However, the presented values were similar or better to the obtained by isotachophoretic determination of the following: lysine, ornithine, arginine, histidine, tyramine and phenylalanine (Jastrzębska et al. 2015); lysine, valine, leucine and isoleucine
(Kovářová et al. 2018); theanine (Kvasnička and Krátká 2006); and arginine, histidine and lysine (Kubačák et al. 2006).

The coefficient of determination $\left(R^{2}\right)$ was close to one, which indicated satisfactory linearity between zone length and the concentration of Trp solution. For comparison, the presented $R^{2}$ value was similar to those obtained with HPLC method ("RP-HPLC Procedure") and obtained by others ( $\mathrm{Li}$ et al. 2012; Shi et al. 2009). The detection limit of the proposed method was sufficiently low for the determination of the Trp in food samples. Moreover, the quantification limit indicated that Trp could be determined with required precision. 
Table 1 RSH value for standard solution of Trp and linear regression calibration parameters of Trp determination by ITP method

\begin{tabular}{llllllllll}
\hline & $\mathrm{RSH}^{\mathrm{a}}$ & $\mathrm{CV}_{\mathrm{RSH}}{ }^{\mathrm{a}}(\%)$ & $\mathrm{RSH}^{\mathrm{b}}$ & $\mathrm{CV}_{\mathrm{RSH}^{\mathrm{b}}}(\%)$ & $a$ & $b$ & $R^{2}$ & $\begin{array}{l}\text { LOD } \\
\mathrm{mg} \mathrm{L}^{-1}\end{array}$ \\
\hline $\mathrm{Trp}^{\mathrm{c}}$ & 0.698 & 0.52 & 0.697 & 4.83 & 0.3543 & $(-) 2.8610$ & 0.9994 & 2.85 & 8.62 \\
$\operatorname{Trp}^{\mathrm{d}}$ & 0.694 & 1.17 & 0.696 & 2.64 & 0.3390 & $(-) 2.9095$ & 0.9991 & 2.59 & 7.86 \\
\hline
\end{tabular}

where: RSH—relative step height; $(\mathrm{RSH}=(\mathrm{HX}-\mathrm{HL}) /(\mathrm{HT}-\mathrm{HL})$, where HX-zone height of tested ion, HL and HT - step height of leading and terminating ion, respectively); CV — coefficient of variation; a — slope of the line; $\mathrm{b}$-intercept on the $y$-axis, $R^{2}$ —coefficient of determination; $\mathrm{LOD}$ (detection limit) $\left(\mathrm{mg} \mathrm{L}^{-1}\right)=\left(3 \cdot \mathrm{s}_{\mathrm{y} / \mathrm{x}}\right) \mathrm{a}^{-1} ; \mathrm{LOQ}$ (quantification limit) $\left(\mathrm{mg} \mathrm{L}^{-1}\right)=\left(10 \cdot \mathrm{S}_{\mathrm{y} / \mathrm{x}}\right) \mathrm{a}^{-1}$. Each solution was analysed in triplicate

${ }^{\text {a }}$ One-day analysis of Trp solution

${ }^{\mathrm{b}}$ Five-day analysis of Trp solution

${ }^{\mathrm{c}}$ Standard solution of Trp

${ }^{\mathrm{d}}$ Blank matrix solution with Trp
The slope comparison method was used to evaluate the matrix effect (Jia et al. 2011). For this purpose, the beverage samples were spiked with appropriate amounts of Trp standards ("Validation Study of ITP Procedure") and used to construct calibration curves. The ratio between the slopes (matrix curve and Trp standards curve) was calculated and obtained value was 0.96 . This fact pointed that there were no significant matrix effects in relatively complex food matrices. In comparison, for HPLC procedure, the value of slope ratio of matrix/ standard solutions was 1 . Furthermore, Student's $t$ test was applied to determine the differences of calibration slopes between solutions and indicate lack of significant differences at 95\% confidence level.

Selectivity of the proposed procedure for Trp separation was tested using single solution of all LNAA: Tyr, Thr, Met, Val, Leu, Ile and His; remaining essential amino acids: Phe, Arg, Gly, Lys, Ala, Glu and Pro; and decarboxylation product of tryptophan: tryptamine. All tested compounds were identified by the RSH parameter, and obtained values are presented in Table 2, whereas isotachopherogram of amino acids standard solutions mixture is presented on Fig. 2.

The data collected in Table 2 confirmed that Trp was satisfactory separated from other compounds in one ITP run. Separations of single amino acid yielded coefficient of variation (CV) in the range $0.6-1.54 \%$, indicating acceptable repeatability of the relative step height parameters. The RSH data for tested compounds suggested that some of the amino acids co-migrated. Phe + His + Met + Tyr and Leu + Ile migrated together in a mixed zones with an average value of
$\mathrm{RSH}=0.559$ and $\mathrm{RSH}=0.945$, respectively. The most abundant amino acids in beer are Pro, Ala, Tyr, Phe, Arg, Glu and Leu (Guo et al. 2019; Poveda 2019; Redruello et al. 2017). It is evident that any of them did not affect the separation and quantification of Trp.

The data of recovery test, based on analysis of Trp mixtures with other amino acids by ITP and HPLC procedures, are collected in Table 3. The typical isotachopherograms are presented on Fig. 3.

The obtained values of recovery for ITP varied from 96.6 to $101.4 \%$ and pointed satisfactory accuracy of the discussed procedure. Moreover, $\mathrm{CV}$ data for RSH and zone length varied from 0.52 to $1.87 \%$ and from 2.23 to $3.46 \%$, respectively, and confirmed satisfactory precision for qualitative and quantitative analysis of Trp.

\section{Chromatographic Separation of Free Trp}

The chromatogram profile of selected amino acids derivatives with CNBF is shown in Fig. 4.

Good chromatographic separation was demonstrated for most of amino acids; however, peak resolution for tryptophan and leucine + isoleucine was not satisfactory. This problem was illustrated by the accuracy for Trp analysis in the presence of leucine and/or isoleucine (Table 3). The recovery values for Trp in mixture containing Ile and/or Leu and without these amino acids varied from 104.9 to $117.5 \%$ and from 95.0 to $99.4 \%$, respectively. Moreover, the intraday precision of Trp peak

Table 2 The data of qualitative analysis for ITP procedure

\begin{tabular}{llllllllllllllll}
\hline & Glu & Thr & Met & Tyr & Phe & His & Trp & Val & Ile & Leu & Arg & Pro & Lys & Gly & Ala \\
\hline RSH & 0.369 & 0.457 & 0.541 & 0.557 & 0.562 & 0.565 & 0.698 & 0.834 & 0.915 & 0.920 & Not detected & & \\
CV $(\%)$ & 1.54 & 0.64 & 1.04 & 1.02 & 1.14 & 1.05 & 0.52 & 0.58 & 1.20 & 0.97 & & & \\
\hline
\end{tabular}

Each standard solution was analysed in triplicate

Arg arginine, His histidine, Ile isoleucine, Leu leucine, Lys lysine, Met methionine, Phe phenylalanine, Pro proline, Thr threonine, Tyr tyrosine, Val valine, Glu glutamic acid, Gly glycine, Ala $\beta$-alanine, Trp tryptamine, $R S H$ relative step height parameter, $C V$ coefficient of variation (\%) 
Fig. 2 Isotachopherograms of standard mixture, where: $\mathrm{Thr}$ threonine, Phe phenylalanine, His histidine, Met methionine, Tyr tyrosine, Trp tryptophan, Val valine, Leu leucine, Ile isoleucine

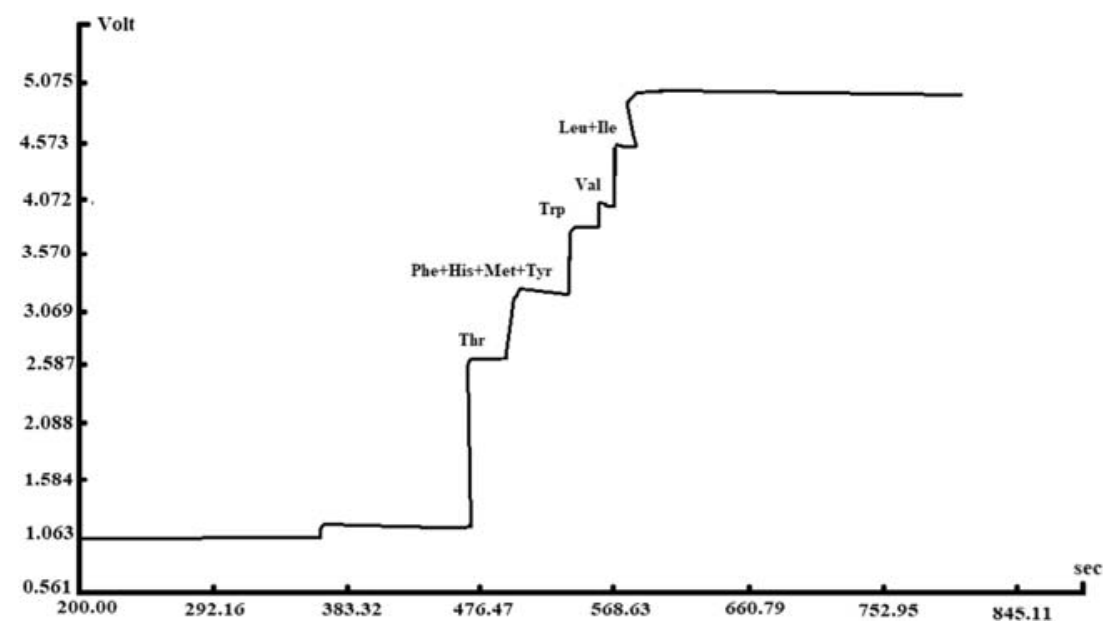

retention time and peak area analysis was characterized by higher values of coefficient variation in comparison to ITP procedure.

The proposed ITP procedure of Trp analysis in standard and blank samples revealed satisfactory selectivity, linearity, precision and accuracy. Moreover, ITP significantly reduces required steps and time of sample preparation resulting in the satisfactory analytical throughput. Results of amino acids separation by HPLC and ITP procedures indicated better accuracy for the latter.

\section{Beer Sample Analysis}

The applicability of the ITP and HPLC methods was evaluated in beer samples (Table 4). The typical isotachopherograms and chromatograms for beer samples are presented on Figs. 5 and 6.

Based on the ITP procedures, the tryptophan was found in 12 beer samples and varied from $7.76 \pm 0.44 \mathrm{mg} \mathrm{L}^{-1}$ (sample 7lager) to $40.74 \pm 0.27 \mathrm{mg} \cdot \mathrm{L}^{-1}$ (sample 16-blackberry beer drink). In the case of samples 6 and 7, low concentration of studied amino acid was observed (below LOQ); for this reason, the standard addition method was applied for quantification. For comparison, the amount of Trp in different beer samples varied between 33.7 and $52.3 \mathrm{mg} \mathrm{L}^{-1}$ (Sikorska et al. 2008) and from 4.8 to $31.1 \mathrm{mg} \mathrm{L}^{-1}$ (Y1lmaz and Gökmen 2018), whereas occasionally in beer samples, Trp was not detected (Kabelová et al. 2008; Shi et al. 2009). Concentration of this amino acid in seven types of beers varied from undetectable level (Belgian origin, Abbey beer, Trapense beer, Double malt beer, Wheat beer) to $31.9 \mathrm{mg} \mathrm{L}^{-1}$ (Red malt beer) (Cortacero-Ramírez et al. 2004). Poveda (2019) analysed the concentrations of biogenic amines and free amino acids in different craft beers and pointed Trp contents from 8.5 to $32.3 \mathrm{mg} \mathrm{L}^{-1}$ (wheat pale beer), from 2.4 to $31.5 \mathrm{mg} \mathrm{L}^{-1}$ (dark beer) and from 3.0 to $44.1 \mathrm{mg} \mathrm{L}^{-1}$ (pale beer), respectively. It can be concluded that the tested beverages from Polish brands are characterized by similar content of Trp.

The studied beers represented the type of yeast used to ferment it: top fermentation (ale, wheat) and bottom fermentation (pilsner, hop, porter, lager, unpasteurized lager and strong lager) and two beer drinks combining beer and apple or blackberry juice in a $45 / 55 \%$ ratio. Based on the obtained results, we can conclude that the type of fermentation does not significantly affect the amount of free Trp in tested beverages. Moreover, no significant relationship between contents of Trp and alcohol by volume or types of beer (pale, dark, wheat,

Table 3 The recovery values of Trp determination in amino acids mixtures for ITP and HPLC procedures

\begin{tabular}{|c|c|c|c|c|c|c|}
\hline \multirow[t]{2}{*}{ Composition of the mixture } & \multicolumn{3}{|l|}{ ITP } & \multicolumn{3}{|l|}{ HPLC } \\
\hline & $\begin{array}{l}\text { Recovery of } \\
\operatorname{Trp}(\%)\end{array}$ & $\begin{array}{l}\mathrm{CV}_{\mathrm{RSH}} \\
(\%)\end{array}$ & $\begin{array}{l}\mathrm{CV}_{\mathrm{L}} \\
(\%)\end{array}$ & $\begin{array}{l}\text { Recovery of } \\
\operatorname{Trp}(\%)\end{array}$ & $\begin{array}{l}\mathrm{CV}_{\mathrm{RT}} \\
(\%)\end{array}$ & $\begin{array}{l}\mathrm{CV}_{\mathrm{PA}} \\
(\%)\end{array}$ \\
\hline$\left(20 \mathrm{mg} \mathrm{L}^{-1}\right) \operatorname{Trp}+\left(35 \mathrm{mg} \mathrm{L}^{-1}\right) \mathrm{His}+\left(45 \mathrm{mg} \mathrm{L}^{-1}\right) \mathrm{Val}+\left(10 \mathrm{mg} \mathrm{L}^{-1}\right)$ Leu & 100.9 & 0.52 & 2.51 & 104.9 & 3.15 & 4.5 \\
\hline$\left(50 \mathrm{mg} \mathrm{L}^{-1}\right) \operatorname{Trp}+\left(10 \mathrm{mg} \mathrm{L}^{-1}\right) \mathrm{Ile}+\left(25 \mathrm{mg} \mathrm{L}^{-1}\right) \mathrm{Leu}+\left(50 \mathrm{mg} \mathrm{L}^{-1}\right) \mathrm{Met}$ & 96.6 & 0.81 & 2.23 & 117.5 & 2.97 & 6.8 \\
\hline $\begin{array}{l}\left(75 \mathrm{mg} \mathrm{L}^{-1}\right) \mathrm{Trp}+\left(25 \mathrm{mg} \mathrm{L}^{-1}\right) \mathrm{Phe}+\left(25 \mathrm{mg} \mathrm{L}^{-1}\right) \mathrm{His}+\left(25 \mathrm{mg} \mathrm{L}^{-1}\right) \mathrm{Thr}+\left(25 \mathrm{mg} \mathrm{L}^{-1}\right) \\
\mathrm{Met}+\left(25 \mathrm{mg} \mathrm{L}^{-1}\right) \mathrm{Tyr}+\left(10 \mathrm{mg} \mathrm{L}^{-1}\right) \mathrm{Leu}\end{array}$ & 100.7 & 1.55 & 2.37 & 107.9 & 1.69 & 3.7 \\
\hline$\left(75 \mathrm{mg} \mathrm{L}^{-1}\right) \operatorname{Trp}+\left(10 \mathrm{mg} \mathrm{L}^{-1}\right)$ Phe $+\left(50 \mathrm{mg} \mathrm{L}^{-1}\right)$ Pro & 101.4 & 0.98 & 3.33 & 99.4 & 4.01 & 0.52 \\
\hline $\begin{array}{l}\left(20 \mathrm{mg} \mathrm{L}^{-1}\right) \operatorname{Trp}+\left(10 \mathrm{mg} \mathrm{L}^{-1}\right) \mathrm{Phe}+\left(10 \mathrm{mg} \mathrm{L}^{-1}\right) \mathrm{Val}+\left(10 \mathrm{mg} \mathrm{L}^{-1}\right) \mathrm{Lys}+\left(10 \mathrm{mg} \mathrm{L}^{-1}\right) \\
\mathrm{Thr}+\left(10 \mathrm{mg} \mathrm{L}^{-1}\right) \mathrm{Met}+\left(10 \mathrm{mg} \mathrm{L}^{-1}\right) \mathrm{His}+\left(10 \mathrm{mg} \mathrm{L}^{-1}\right) \mathrm{Tyr}+\left(10 \mathrm{mg} \mathrm{L}^{-1}\right) \text { Pro }\end{array}$ & 100.4 & 1.87 & 3.46 & 95.0 & 2.18 & 1.12 \\
\hline
\end{tabular}

Each mixture was analysed in triplicate. Recovery was calculated as mean value of (obtained concentration/theoretical concentration) $100 \%$

Arg arginine, His histidine, Ile isoleucine, Leu leucine, Lys lysine, Met methionine, Phe phenylalanine, Pro proline, Thr threonine, Trp tryptophan, Tyr tyrosine, Val valine, $C V$ coefficient of variation $(\%), R S H$ relative step height, $L$ zone length, $R T$ retention time, $P A$ peak area 
a

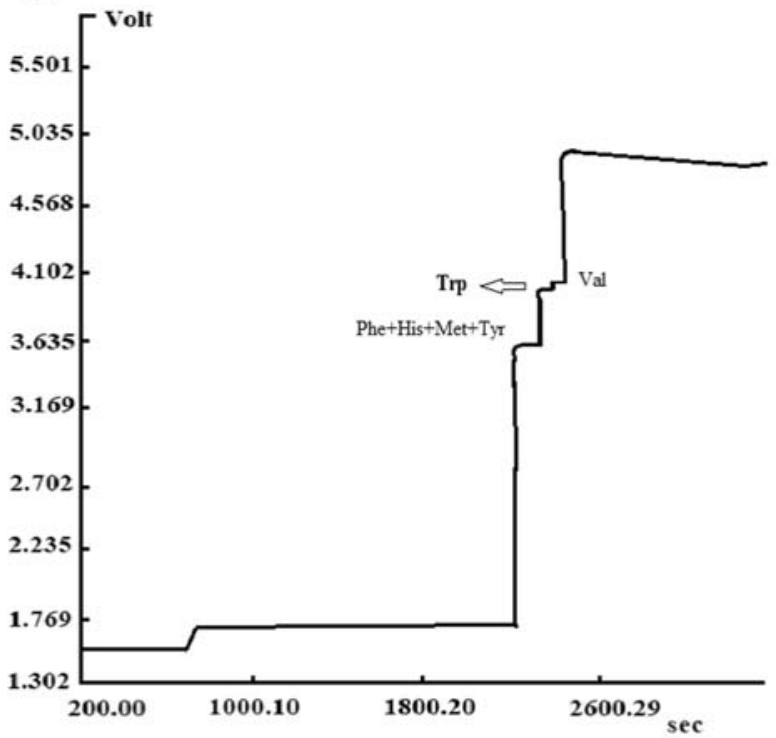

C

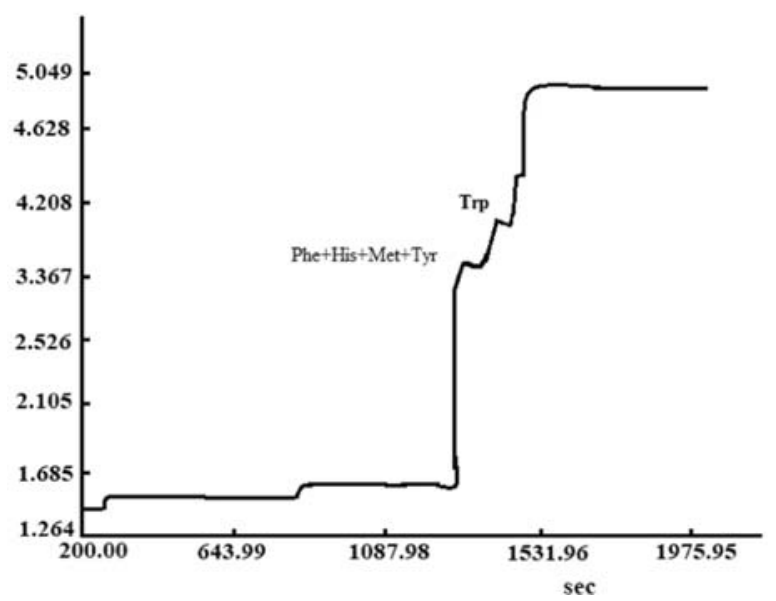

b

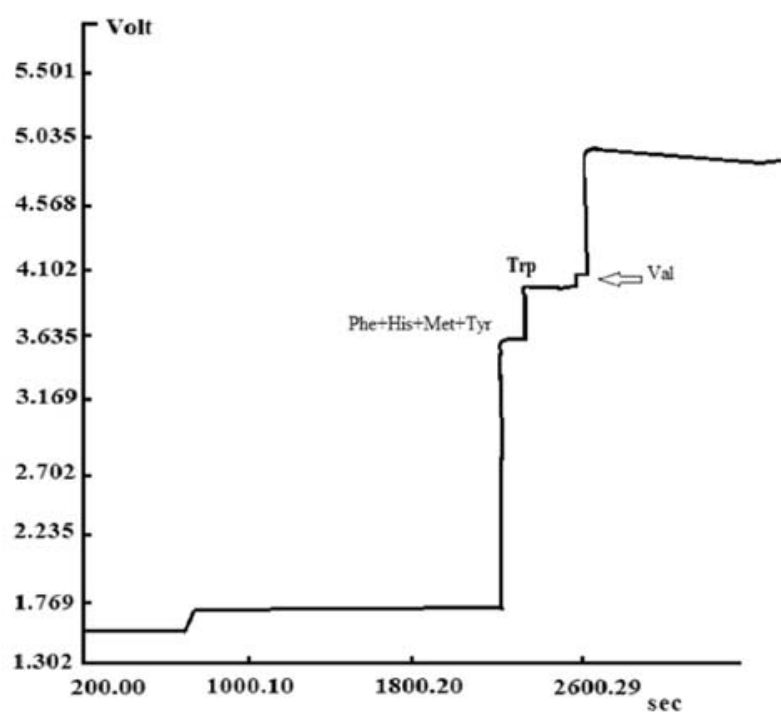

d

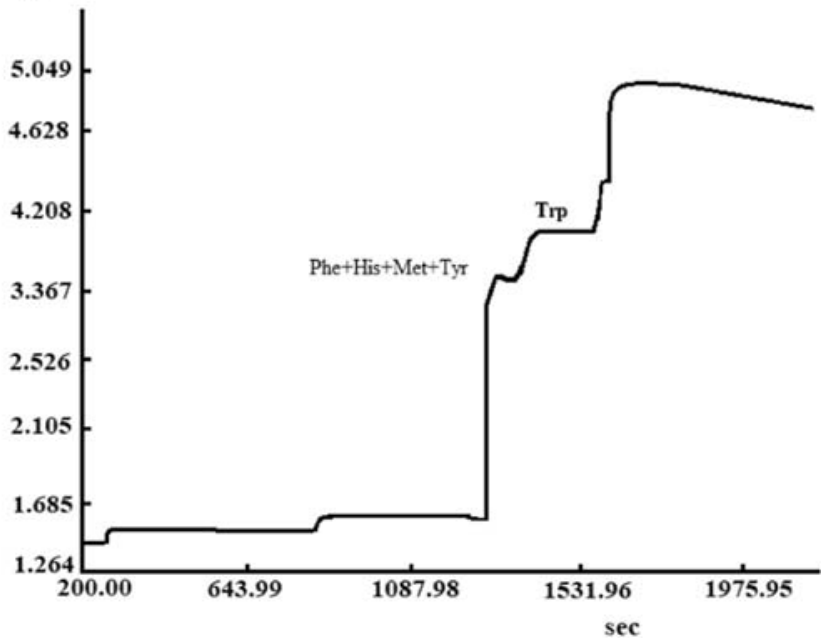

Fig. 3 The isotachopherograms of beer samples for standard addition method, where a sample 1 (strong lager), b sample 1 (strong lager) with Trp (75 $\left.\mathrm{mg} \mathrm{L}^{-1}\right)$, c sample 16 (blackberry beer drink) and d sample 16 (blackberry beer drink) with $\operatorname{Trp}\left(20 \mathrm{mg} \mathrm{L}^{-1}\right)$

hop, pasteurized or unpasteurized) was found. However, for four samples of beer from microbrewery (samples 3, 5, 10 and 14), regardless of the type of beer, the presence of Trp was not observed. The variability between samples in terms of Trp content can be attributable to the different origin of raw materials and the style of brewing used in the production process. The free forms of amino acids in beer originate mostly from malt. According to Poveda (2019) during the transformation of wort into beer, the action of cereal proteolytic enzymes releases amino acids from the proteins of barley, hops and malt. Subsequently, amino acids are consumed in part by the yeast during fermentation, and part remains in the beer. Tryptophan is included in the group of amino acids with intermediate absorption by yeast (Kabelová et al. 2008).
However, assimilation pattern is often specific to the conditions employed and among them, the yeast strain's nutritional preferences are more significant. Palomino-Vasco et al. (2019) discussed the concentrations of amino acids in craft beer during the fermentation and in the bottled beer. Authors observed a reduction of Trp concentration during the fermentation from $29 \mathrm{mg} \mathrm{L}^{-1}$ to undetected. However, the content of Trp was increased on the last day before bottling and in the bottled beer was on similar level to first day of fermentation. Summarizing, the differences in the Trp contents in tested beer samples seem to be related to the brewery (craft or global brewery) and used raw materials.

Comparing the obtained results of Trp determination by ITP procedure with those obtained by HPLC, it is evident that 
Fig. 4 Chromatogram of amino acids mixture (A), where: 1 - His, 2-Thr, 3-Arg, 4-Tyr, 5-Val, 6-Met, 7-Trp, 8-Leu + Ile, 9-Phe, 10-Lys, 11-CNBF and (B) mixture of Trp (1) with Leu and Ile (2)

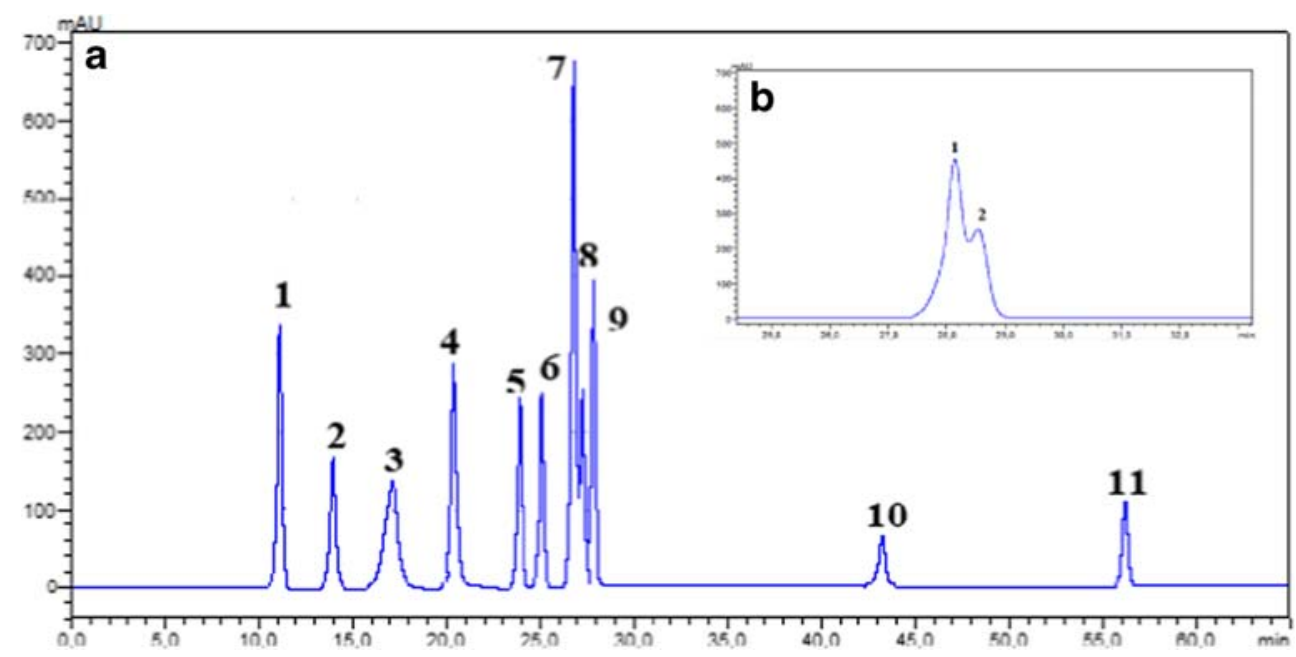

the obtained data were on the similar level (Table 4). The difference between the procedures varied from $0.12 \mathrm{mg} \mathrm{L}^{-1}$ (sample 6) to $16.83 \mathrm{mg} \mathrm{L}^{-1}$ (sample 11). However, HPLC procedure allowed to determination of Trp at lower content level than ITP (sample 10). The values of CV indicated similar precision for both procedures. In the case of accuracy, recoveries were in the range $96.7-100.1 \%$ and $93.9-107.8 \%$ for ITP and HPLC procedures, respectively. Going further, the
Table 4 The content of free tryptophan determination in beverage samples $\left(\mathrm{mg} \mathrm{L}^{-1}\right)$ by ITP and HPLC methods, $n=3$

\begin{tabular}{|c|c|c|c|c|c|c|}
\hline \multirow[t]{2}{*}{ Sample } & \multicolumn{3}{|l|}{ ITP } & \multicolumn{3}{|l|}{ HPLC-CNBF } \\
\hline & $\mathrm{X} \pm \mathrm{SD}\left(\mathrm{mg} \mathrm{L}^{-1}\right)$ & $\mathrm{CV}(\%)$ & $\operatorname{Recovery}^{\mathrm{a}}(\%)$ & $\mathrm{X} \pm \mathrm{SD}\left(\mathrm{mg} \mathrm{L}^{-1}\right)$ & CV $(\%)$ & Recovery $^{\mathrm{a}}(\%)$ \\
\hline 1 & $21.62 \pm 0.39$ & 1.81 & 97.4 & $21.36 \pm 0.35$ & 1.65 & 98.5 \\
\hline 2 & $40.36 \pm 0.04$ & 0.11 & 98.5 & $42.29 \pm 1.34$ & 3.34 & 99.4 \\
\hline 3 & nd & - & - & nd & - & - \\
\hline 4 & $22.33 \pm 0.66$ & 2.97 & 95.9 & $37.56 \pm 0.68$ & 1.80 & 107.8 \\
\hline 5 & nd & - & - & nd & - & - \\
\hline 6 & $8.18 \pm 0.10^{b}$ & 1.22 & - & $8.30 \pm 0.16$ & 1.88 & 94.8 \\
\hline 7 & $7.76 \pm 0.44^{\mathrm{b}}$ & 5.71 & - & $11.47 \pm 0.59$ & 5.19 & 106.7 \\
\hline 8 & $24.25 \pm 0.61$ & 2.49 & 99.1 & $35.44 \pm 0.20$ & 0.58 & 103.2 \\
\hline 9 & $32.12 \pm 0.45$ & 1.41 & 100.1 & $30.83 \pm 1.60$ & 5.19 & 96.2 \\
\hline 10 & nd & - & - & $6.90 \pm 0.35$ & 5.07 & 93.9 \\
\hline 11 & $27.66 \pm 0.26$ & 0.93 & 98.6 & $44.49 \pm 0.09$ & 0.19 & 105.2 \\
\hline 12 & $19.92 \pm 0.86$ & 4.33 & 97.5 & $22.91 \pm 0.91$ & 3.98 & 102.2 \\
\hline 13 & $31.79 \pm 0.24$ & 0.77 & 97.6 & $32.68 \pm 0.17$ & 0.52 & 104.3 \\
\hline 14 & nd & - & - & nd & - & - \\
\hline 15 & $31.41 \pm 0.24$ & 0.75 & 99.2 & $33.47 \pm 0.40$ & 1.20 & 99.7 \\
\hline 16 & $40.74 \pm 0.27$ & 0.66 & 96.7 & $41.31 \pm 1.05$ & 2.54 & 95.6 \\
\hline
\end{tabular}

Where: 1-strong lager; 2 - unpasteurized lager; 3-unpasteurized lager; 4 - pilsner; 5-pilsner; 6-lager; 7 lager; 8 -wheat; 9-hop; 10-hop; 11-porter; 12-porter; 13-ale; 14-ale; 15-apple beer drink; 16blackberry beer drink

$\mathrm{X} \pm \mathrm{SD}$ — average value with standard deviation $\left(\mathrm{mg} \mathrm{L}^{-1}\right) ; \mathrm{CV}$ — coefficient of variation (\%); $n=3$ - number of independent samples, each sample was analysed in triplicate

${ }^{\text {a }}$ Average recovery (calculated by adding a known amount of Trp to the beer samples and analysis of unspiked and spiked samples)

${ }^{\mathrm{b}}$ Calculated from standard addition method 
Fig. 5 The isotachopherograms of beer samples: a sample 2

(unpasteurized lager), b sample

11 (porter) and $\mathbf{c}$ sample 13 (ale)

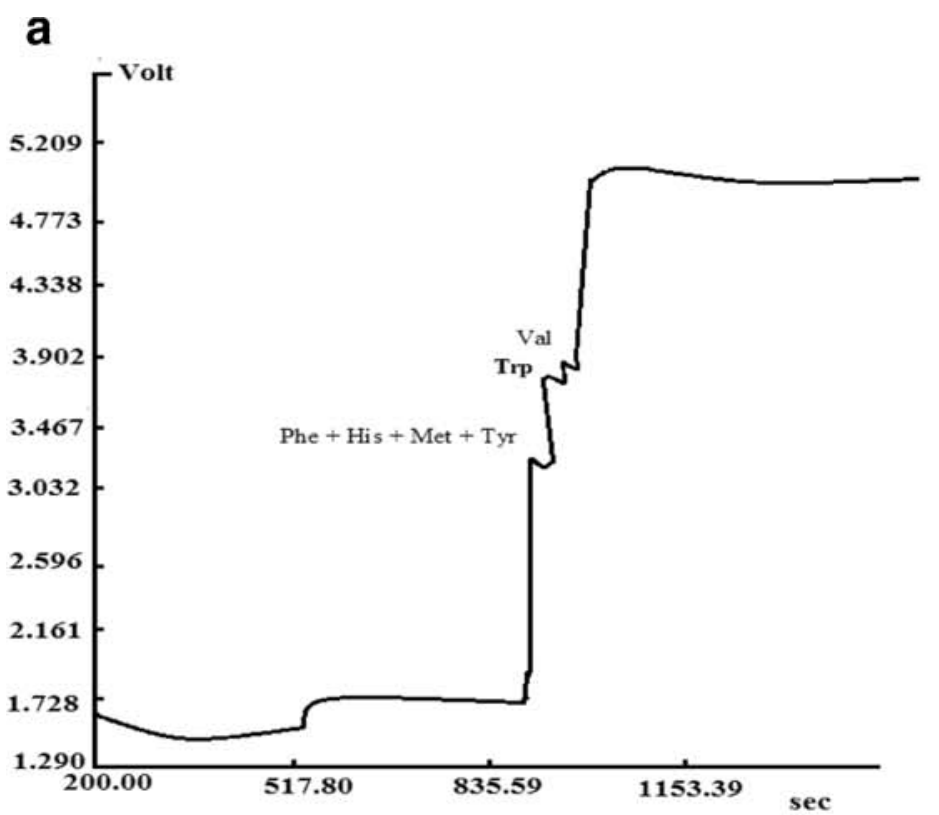

b

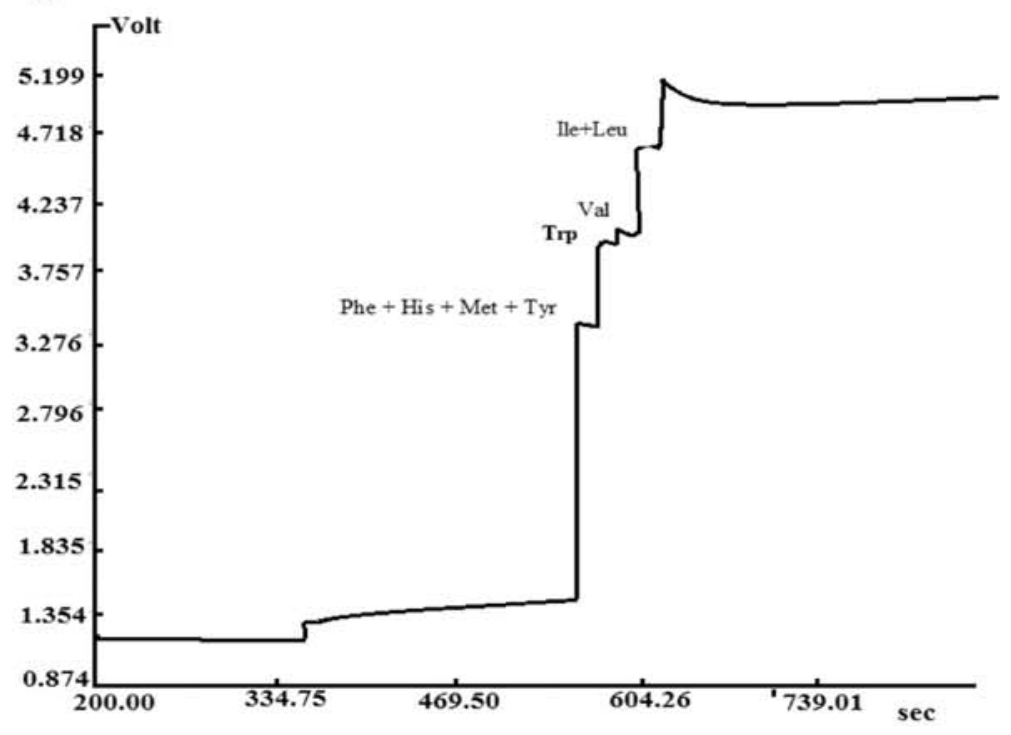

C

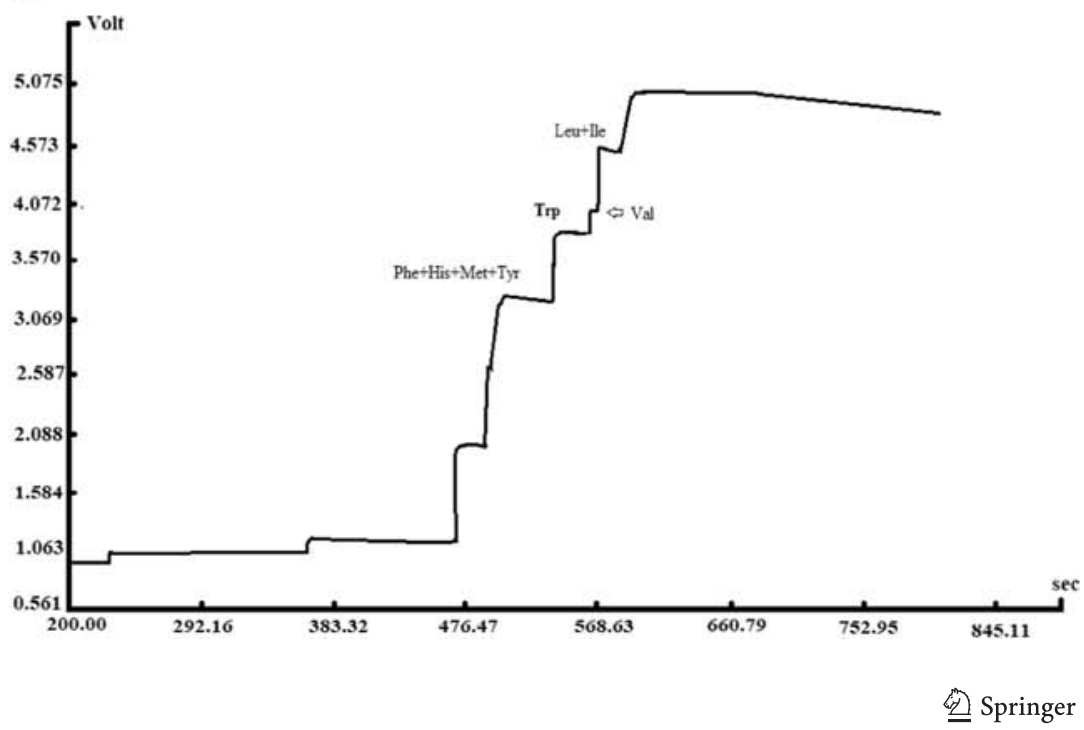


Fig. 6 The chromatograms of beer samples: a sample 8 (wheat) b sample 11 (porter), where: $\mathrm{x}$ unknown, 1 - Glu, 2-His, 3 Pro, 4-Arg, 5-Gly, 6-Tyr, 7-Val, 8-Trp, 9-Leu + Iso, 10 - Phe, $11-\mathrm{CNBF}$ a

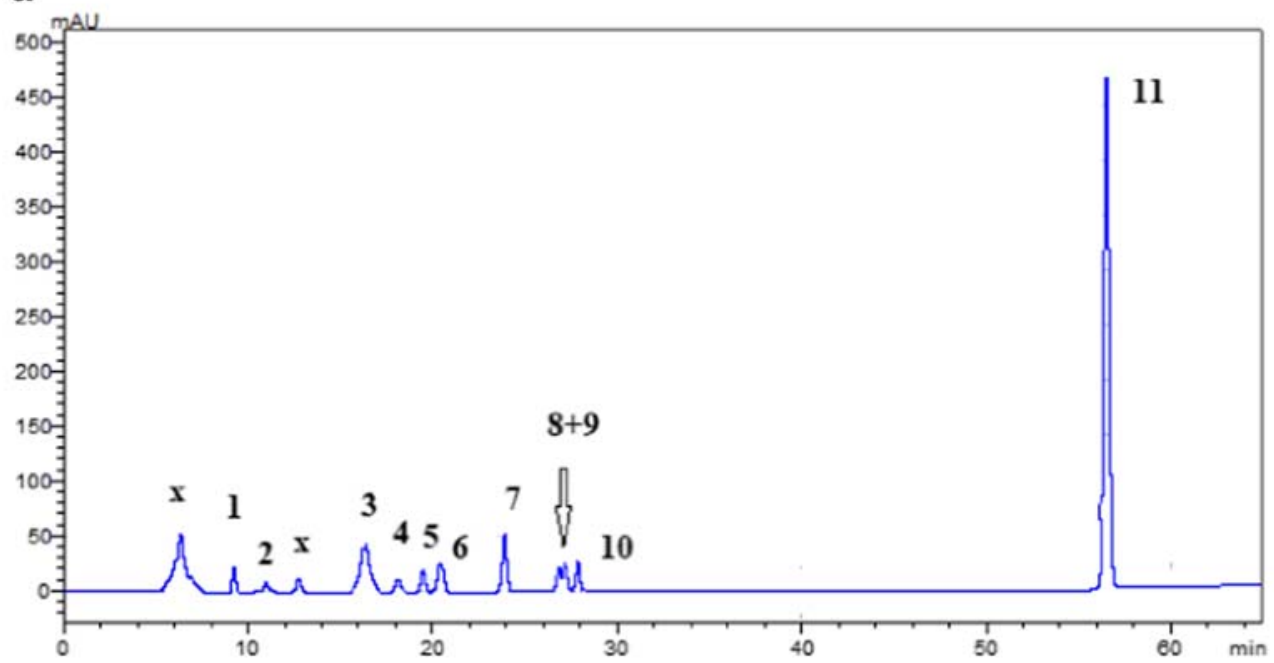

b

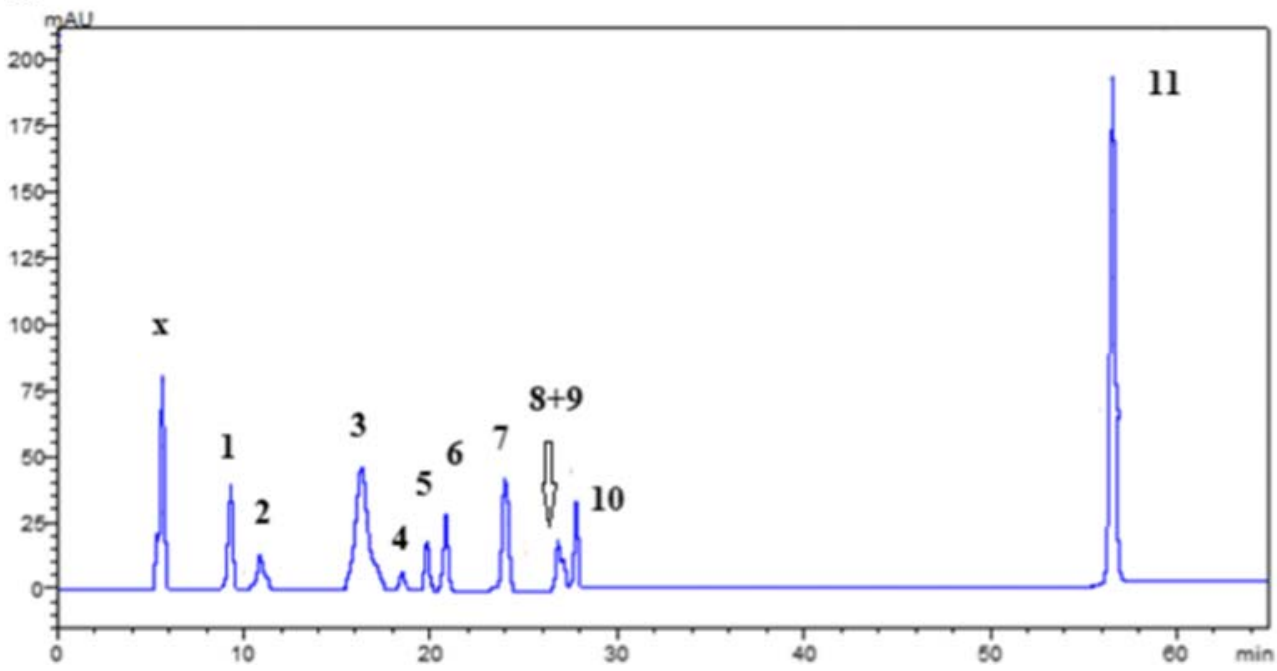

precision and accuracy of procedure depended on the sample preparation method. In this paper, determination of Trp in beer samples required only sonification to remove carbonation, filtration if sample was cloudy followed by derivatization for HPLC or water dilution for ITP. Based on the obtained results of recovery for HPLC procedure, poor resolution between Trp and Ile and Leu was observed (Fig. 6). The latter shows that the matrix interferences in complex samples for HPLC analysis cannot be eliminated efficiently although derivatization can improve the selectivity and sensitivity (Guo et al. 2015). It should be emphasized that this problem was minimized in the proposed ITP procedure.

Comparing the data of $\mathrm{CV}$ and recoveries obtained in this study for ITP procedure with those described by others ( $\mathrm{Li}$ et al. 2012; Shi et al. 2009; Sikorska et al. 2008; Y1lmaz and Gökmen 2018), the similar precision and accuracy of the proposed method were revealed.

Finally, the obtained results of Trp analysis by ITP and HPLC were compared by one-way ANOVA, followed by the Duncan test. Generally, mean value of Trp in beer samples did not show significant differences, with three exceptions (samples 4, 8 and 11). The latter suggested that ITP results significantly correlate with the one obtained by HPLC procedure.

\section{Conclusion}

The paper demonstrated the first application of capillary isotachophoresis for determination of free tryptophan in beer samples. The discussed procedure offers advantages such as simplicity, satisfactory accurace, precision and selectivity, low cost and eco-friendliness. The results of free Trp determination in beer samples were compared with the one obtained by chromatographic procedure, and ITP was characterized by better selectivity and accuracy with satisfactory separation, linearity, limits of detection and quantification and precision. The proposed ITP procedure considerably reduced the time 
required for sample preparation procedures, and there are no significant matrix effects for the complex food matrices. The described advantages of isotachophoretic procedure suggest its application for the tryptophan determination in various food samples.

Funding Information The authors received financial support from Nicolaus Copernicus University in Torun (grant no. 252) for this study.

\section{Compliance with Ethical Standards}

Conflict of Interest Aneta Jastrzęska declares that she has no conflict of interest. Sylwia Kowalska declares that she has no conflict of interest. Edward Szłyk declares that he has no conflict of interest.

Ethical Approval This article does not contain any studies with human participants or animals performed by any of the authors.

Open Access This article is licensed under a Creative Commons Attribution 4.0 International License, which permits use, sharing, adaptation, distribution and reproduction in any medium or format, as long as you give appropriate credit to the original author(s) and the source, provide a link to the Creative Commons licence, and indicate if changes were made. The images or other third party material in this article are included in the article's Creative Commons licence, unless indicated otherwise in a credit line to the material. If material is not included in the article's Creative Commons licence and your intended use is not permitted by statutory regulation or exceeds the permitted use, you will need to obtain permission directly from the copyright holder. To view a copy of this licence, visit http://creativecommons.org/licenses/by/4.0/.

\section{References}

Cortacero-Ramírez S, Segura-Carretero A, Cruces-Blanco C, RomeroRomero ML, Fernández-Gutiérrez A (2004) Simultaneous determination of multiple constituents in real beer samples of different origins by capillary zone electrophoresis. Anal Bioanal Chem 380: 831-837. https://doi.org/10.1007/s00216-004-2806-8

de Gaetano G, Costanzo S, Di Castelnuovo A, Badimon L, Bejko D, Alkerwi A, Chiva-Blanch G, Estruch R, La Vecchia C, Panico S, Pounis G, Sofi F, Stranges S, Trevisan M, Ursini F, Cerletti C, Donati MB, Iacoviello L (2016) Effects of moderate beer consumption on health and disease: a consensus document. Nutr Metab Cardiovas Dis 26:443-467. https:// doi.org/10.1016/j.numecd.2016.03.007

Everaerts FM, Beckers JL, Verheggen TPEM (1976) Isotachophoresis, theory, instrumentation and applications. Elsevier Scientific Publishing Company, Amsterdam

Fontana M, Buiatti S (2009) Amino acids in beer. In: Preedy V (ed) Beer in health and disease prevention, 1st edn. Elsevier Inc., USA, pp 273-284

Friedman M (2018) Analysis, nutrition, and health benefits of tryptophan. Int J Try Res 11:1-12. https://doi.org/10.1177/117864691880228

Gebauer P, Boček P (1997) Recent application and developments of capillary isotachophoresis. Electrophoresis 18:2154-2161

Gil-Agustí M, Carda-Broch S, Ll M-P, Esteve-Romero J (2007) Simultaneous determination of tyramine and tryptamine and their precursor amino acids by micellar liquid chromatography and pulsed amperometric detection in wines. J Chromatogr A 1156: 288-295. https://doi.org/10.1016/j.chroma.2007.02.090
Guo M, Shi T, Duan Y, Zhu J, Li J, Cao Y (2015) Investigation of amino acids in wolfberry fruit (Lycium barbarum) by solid-phase extraction and liquid chromatography with precolumn derivatization. J Food Comp Anal 42:84-90. https://doi.org/10.1016/j.jfca.2015.03.004

Guo C, Guo Z, Chen Y (2019) A bi-end injection capillary electrophoresis method for simultaneous determination of 37 cations and anions in beers. Anal Bioanal Chem 411:4113-4121. https://doi.org/10. 1007/s00216-018-1507-7

Hirokawa T, Nishino M, Aoki N, Kiso Y, Sawamoto Y, Yagi T, Akiyama JI (1983) Table of isotachophoretic indices. I. Simulated qualitative and quantitative indices of 287 anionic substances in the range $\mathrm{pH}$ 3-10. J Chromatogr 271:D1-D106. https://doi.org/10.1016/S00219673(00)80225-3

Hirokawa T, Taka T, Yokota Y, Kiso Y (1991) Dilution effect of carbonate ion on isotachophoretic zones observed with scanning UV photometric detection. J Chromatogr 555:247-253. https://doi.org/10. 1016/S0021-9673(01)87185-5

Huang C-Y, Wang Y-X, Wang X-Z, Hu C-C, Chiu T-C (2019) Analysis of seven biogenic amines and two amino acids in wines using micellar electrokinetic chromatography. Appl Sci 9:1193-1204. https://doi. org/10.3390/app9061193

Jastrzębska A, Piasta A, Filipiak-Szok A, Szłyk E (2013) Optimization of capillary isotachophoretic method for histidine determination in protein matrices. Anal Lett 46:1364-1378. https://doi.org/10.1080/ 00032719.2012.762582

Jastrzębska A, Piasta AM, Szłyk E (2015) Elaboration of food sample preparation procedure for free amino acids determination by capillary isotachophoresis. J Food Comp Anal 40:136-142. https://doi. org/10.1016/j.jfca.2015.01.004

Jenkins TA, Nguyen JCD, Polglaze KE, Bertrand PP (2016) Influence of tryptophan and serotonin on mood and cognition with a possible role of the gut-brain axis. Nutrients 8:56-71. https://doi.org/10.3390/ nu8010056

Jia S, Kang YP, Park JH, Lee J, Kwon SW (2011) Simultaneous determination of 23 amino acids and 7 biogenic amines in fermented food samples by liquid chromatography/quadrupole time-of-flight mass spectrometry. J Chromatogr A 1218:9174-9182. https://doi.org/10. 1016/j.chroma.2011.10.040

Kabelová I, Dvořáková M, Ćižková H, Dostálek P, Melzoch K (2008) Determination of free amino acids in beers: a comparison of Czech and foreign brands. J Food Comp Anal 21:736-741. https://doi.org/ 10.1016/j.jfca.2008.06.007

Ke J, Dong Y, Luo T, Xie Y (2017) Development of a gradient micellar liquid chromatographic method eluting from micellar mode to high submicellar mode for the rapid separation of free amino acids. Anal Methods 9:1762-1770. https://doi.org/10.1039/c6ay03453e

Ke J, Duan X-Y, Liu X-F, Dong Y-M (2019) Isocratic micellar liquid chromatography using mixed anionic and non-ionic surfactants as mobile phase additives for separation of 17 free amino acids. Chem Papers 73:2417-2426. https://doi.org/10.1007/s11696-019-00791-0

Kováŕová M, Bartoš M, Mikysek T, Hloušková D, Hyhlíková B, Vladyková J (2018) Isotachophoretic determination of amino acids after their conversion to hydroxy acids. Monats Chem 149:17091718. https://doi.org/10.1007/s00706-018-2220-0(-volV)

Kubačák P, Mikuš P, Valášková I, Havránek E (2006) Simultaneous determination of essential basic amino acids in pharmaceuticals by capillary isotachophoresis. Arch Pharm 339:96-99. https://doi.org/ 10.1002/ardp.200500131

Kvasnička F, Krátká J (2006) Isotachophoretic determination of theanine. Cent Eur J Chem 4:216-222. https://doi.org/10.2478/s11532-0060014-4

Li W, Hou M, Cao Y, Song H, Shi T, Gao X, Wang D (2012) Determination of 20 free amino acids in asparagus tin by highperformance liquid chromatographic method after pre-column derivatization. Food Anal Methods 5:62-68. https://doi.org/10.1007/ s12161-011-9197-1 
Liyanaarachchi GVV, Mahanama KRR, Somasiri HPPS, Punyasiri PAN (2018) Validation of a reversed-phase high-performance liquid chromatographic method for the determination of free amino acids in rice using L-theanine as the internal standard. Food Chem 240:196-203. https://doi.org/10.1016/j.foodchem.2017.07.038

Luo T, Ke J, Xie Y, Dong Y (2017) Determination of underivatized amino acids to evaluate quality of beer by capillary electrophoresis with online sweeping technique. J Food Drug Anal 25:789-797. https:// doi.org/10.1016/j.jfda.2017.03.003

Malá Z, Gebauer P (2019) Recent progress in analytical capillary isotachophoresis. Electrophoresis 40:55-64. https://doi.org/10. 1002/elps.201800239

Markus CR (2008) Dietary amino acids and brain serotonin function; implications for stress-related affective changes. NeuroMolecular Med 10:247-258. https://doi.org/10.1007/s12017-008-8039-9

Moreno-Rojas JM, Moreno-Ortega A, Ordóñez JL, Moreno-Rojas R, Pérez-Aparicio J, Pereira-Caro G (2018) Development and validation of UHPLC-HRMS methodology for the determination of flavonoids, amino acids and organosulfur compounds in black onion, a novel derived product from fresh shallot onions (Allium cepa var. aggregatum). LWT - Food Sci Technol 97:376-383. https://doi.org/ 10.1016/j.lwt.2018.07.032

Palomino-Vasco M, Acedo-Valenzuela MI, Rodríguez-Cáceres MI, Mora-Diez N (2019) Automated chromatographic method with fluorescent detection to determine biogenic amines and amino acids. Application to craft beer brewing process. J Chromatogr A 1601: 155-163. https://doi.org/10.1016/j.chroma.2019.04.063

Piasta AM, Jastrzębska A, Krzemiński MP, Muzioł TM, Szłyk E (2014) New procedure of selected biogenic amines determination in wine samples by HPLC. Anal Chim Acta 834:58-66. https://doi.org/10. 1016/j.aca.2014.05.028

Poveda JM (2019) Biogenic amines and free amino acids in craft beers from the Spanish market: a statistical approach. Food Control 96: 227-233. https://doi.org/10.1016/j.foodcont.2018.09.012

Prest JE, Baldock SJ, Fielden PR, Goddard NJ, Brown BJT (2004) Analysis of amino acids by miniaturised isotachophoresis. J Chromatogr A 1051:221-226. https://doi.org/10.1016/j.chroma. 2004.05.026

Redruello B, Ladero V, del Rio B, Fernández M, Martin MC, Alvarez MA (2017) A UHPLC method for the simultaneous analysis of biogenic amines, amino acids and ammonium ions in beer. Food Chem 217: 117-124. https://doi.org/10.1016/j.foodchem.2016.08.040

Shi T, Tang T, Qian K, Wang F, Li J, Cao Y (2009) Highperformance liquid chromatographic method for determination of amino acids by precolumn derivatization with 4-chloro-3, 5-dinitrobenzotrifluoride. Anal Chim Acta 654:154-161. https://doi.org/10.1016/j.aca.2009.09.027

Sikorska E, Gliszczynska-Swigło A, Insinska-Rak M, Khmelinskii I, De Keukeleire D, Sikorski M (2008) Simultaneous analysis of riboflavin and aromatic amino acids in beer using fluorescence and multivariate calibration methods. Anal Chim Acta 613:207-217. https:// doi.org/10.1016/j.aca.2008.02.063

Soh NL, Walter G (2011) Tryptophan and depression: can diet alone be the answer? Acta Neuropsychiatr 23:3-11. https://doi.org/10.1111/j. 1601-5215.2010.00508.x

Tezcan F, Uzașc S, Uyar G, Öztekin N, Erim FB (2013) Determination of amino acids in pomegranate juices and fingerprint for adulteration with apple juices. Food Chem 141:1187-1191. https://doi.org/10. 1016/j.foodchem.2013.04.017

Turkia H, Sirén H, Penttilä M, Pitkänen JP (2015) Capillary electrophoresis with laser-induced fluorescence detection for studying amino acid uptake by yeast during beer fermentation. Talanta 131:366 371. https://doi.org/10.1016/j.talanta.2014.07.101

Xie Y, Luo T, Yang J, Dong Y (2018) Rapid determination of amino acids in beer, red wine, and donkey-hide gelatin by gradient elution of HPLC: from micellar liquid chromatography to high submicellar liquid chromatography. J AOAC Int 101:249-255. https://doi.org/ 10.5740/jaoacint.17-0103

Yan J, Cai Y, Wang Y, Lin X, Li H (2014) Simultaneous determination of amino acids in tea leaves by micellar electrokinetic chromatography with laser-induced fluorescence detection. Food Chem 143:82-89. https://doi.org/10.1016/j.foodchem.2013.07.095

Y1lmaz C, Gökmen V (2018) Determination of tryptophan derivatives in kynurenine pathway in fermented foods using liquid chromatography tandem mass spectrometry. Food Chem 243:420-427. https:/ doi.org/10.1016/j.foodchem.2017.10.004

Zgola-Grześkowiak A, Grześkowiak T (2012) Determination of glutamic acid and aspartic acid in tomato juice by capillary isotachophoresis. Int J Food Prop 15:628-637. https://doi.org/10.1080/10942912. 2010.494759

Zhu L, Hu Z, Gamez G, Law SW, Chen HW, Yang SP, Chingin K, Balabin RM, Wang R, Zhang TT, Zenobi R (2010) Simultaneous sampling of volatile and non-volatile analytes in beer for fast fingerprinting by extractive electrospray ionization mass spectrometry. Anal Bioanal Chem 398:405-413. https://doi.org/10.1007/s00216010-3945-8

Publisher's Note Springer Nature remains neutral with regard to jurisdictional claims in published maps and institutional affiliations. 